\title{
Application of High-tech Solutions in Ecodevelopment
}

\author{
Oleg Korol ${ }^{1}$, Natalia Shushunova ${ }^{1}$, Dmitry Lopatkin ${ }^{2}$, Alexey Zanin $^{3}$ and Tatiana \\ Shushunova $^{4}$ \\ ${ }^{1}$ Moscow State University of Civil Engineering, Yaroslavskoe shosse, 26, Moscow, 129337, Russia \\ ${ }^{2}$ Mendeleyev University of Chemical Technology of Russia, Department of Management and \\ Marketing, Miusskaya square, 9, Moscow, 125047, Russia \\ ${ }^{3}$ Mendeleyev University of Chemical Technology of Russia, Department of UNESCO "Green \\ Chemistry for Sustainable Development", Miusskaya square, 9, Moscow, 125047, Russia \\ ${ }^{4}$ Mendeleyev University of Chemical Technology of Russia, Department of Management and \\ Marketing, Miusskaya square, 9, Moscow, 125047, Russia
}

\begin{abstract}
This research is aimed to study the significant number of negative environmental consequences are due to the active development of cities and agglomerations. The technologies of green buildings are constantly being improved with the aim of reducing the overall influence of development on the environment and human health. Today, one of the most important trends of eco-development is to develop the innovations in the field of green building structures. Green modular roofing structures contribute to solving the problems of ecodevelopment in the construction of smart cities and smart buildings for sustainable development.
\end{abstract}

\section{Introduction}

This research is aimed at studying the high-tech solutions in ecodevelopment and the innovations in the field of green building structures. At present, environmental concerns are growing in the society, which, together with economic and social problems, become sources of serious risks for the opportunities of future generations to satisfy their needs and interests, and for the survival of mankind as a whole. In this regard, the search for solutions to the problems of sustainable development is becoming more urgent. This led to the adoption of the Sustainable Development Goals (SDGs), which were described in detail in the Agenda for Sustainable Development until 2030, at the United Nations Summit in 2015 [1]. These goals officially entered into force on January 1, 2016, and to achieve them by 2030 , it is necessary for countries to intensify efforts to eradicate poverty, combat inequality, tackle climate change, etc. In fact, these goals represent a call to action for improving welfare and ensuring the protection of mankind and the biosphere as a whole.

\footnotetext{
*Corresponding author: nshushun@gmail.com
} 


\section{Methodology}

A significant number of negative environmental consequences are due primarily to the active development of cities and agglomerations. Firstly, cities protect the inhabitants from negative manifestations of climate change. Secondly, on the other hand, typical features of urbanization, including excessive concentration of population, high motorization, pollution of the atmosphere and water bodies are generators of environmental problems and require the development of long-established approaches to managing the development of built-up areas in the direction of ecodevelopment, contributing to the transition to sustainable development, which includes social ecological, and economic well-being of cities.

\subsection{Innovative solutions of green roof system in urban development}

Nowadays smart solutions of green roofs are popular for their ecological, technical, economic benefits and aesthetic qualities. In the conditions of the urban development, the green roofing infrastructures with landscaping environmental elements is gaining popularity (Figure 1). When designing and installing green and blue roofs, it is necessary to take into account the provisions of national regulations and green roof Codes, international standards, that carried out in the green buildings, specific climatic zones of the construction region and other factors in local conditions [2,3]. Application of BIM-modeling technologies contributes to general improvement of the quality of the project documentation and the construction and installation works performed [4].

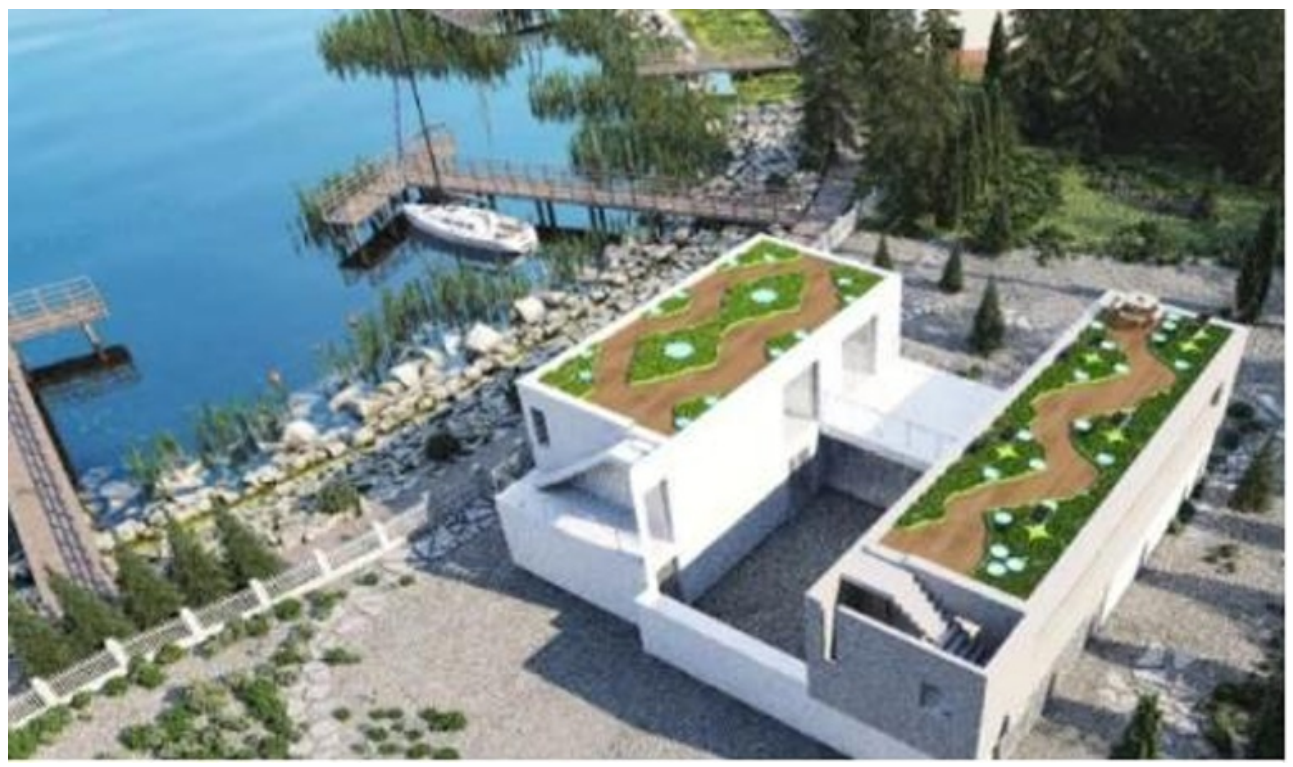

Fig. 1. BIM-modeling of sustainable and future-proof green and blue roof systems in urban space.

Megacities are the centres of a variety of innovations that can contribute to reducing or mitigating emissions, adapting to climate change and the ability to recover. Human activities, such as burning fossil fuels, large-scale industrial construction, deforestation, land-use changes, led, inter alia, to the accumulation of greenhouse gases in the atmosphere, coupled with a decrease in the ability of oceans and vegetation to absorb them. This has reduced the Earth's natural ability to maintain the balance of the carbon cycle and is now directly leading to current global changes in mean temperatures. SDG 11: 
Sustainable cities and settlements (Make cities inclusive, safe, resilient and sustainable) is aimed at solving the problems related to the growth of cities. The high priority of this goal is due to the fact that in cities there are about 3.5 billion people, that is, half of the world population, and by 2030 the share of the urban population will grow to $60 \%$. According to various estimates, cities account for $60-80 \%$ of global energy consumption and $75 \%$ of carbon dioxide emissions, with cities accounting for only $3 \%$ of the land area [1]. To achieve SDG 11, it is necessary to develop more efficient use of resources, reduce the level of environmental pollution and provide adequate housing. New philosophy of creating a comfortable internal (buildings) and external (urban) environment, laying the principles of eco-development is needed to solve the tasks.

The change in approaches to the construction of buildings and structures began in Europe in the middle of 1980 s, primarily as a result of the desire to reduce energy consumption due to the energy crisis of the 1970s. This led to the emergence of requirements for a high level of quality of buildings under construction, which is formed from three fundamental factors of ecodevelopment: special, heightened requirements for the comfort of the building; a significant reduction in the consumption of resources by the object lack of influence of the building on the people in it and the environment.

\subsection{Green standards as a tool for ecodevelopment}

The principles of ecodevelopment aimed at achieving sustainable development goals for cities are developed primarily for large cities and are implemented mainly on a voluntary basis. One of the first tools for eco-development was the "green" standards based on the rating systems for assessing the level of ecological compatibility of buildings, the system for certification of real estate objects: British BRE Environmental Assessment Method (BREEAM) and the American Standard of Leadership in Energy and Environmental Design (LEED) [3,4]. For example, the method of environmental assessment of building efficiency BREEEAM (BRE Environmental Assessment Method) involves a voluntary assessment of the environmental performance of buildings using a rating developed in 1990 by the British organization BRE Global. The BREEAM method is considered to be one of the leading and most widely used methods of environmental assessment of buildings, it is based on the principles of the life cycle analysis of a building and is most often used to evaluate newly constructed buildings. BREEEAM takes into account a wide range of issues of environmental protection and sustainability, which allows designers and developers to confirm the ecological attractiveness of buildings for customers and town planning bodies. BREEAM and LEED (Leadership in Energy and Environmental Design, the American analogue of BREEAM) are characterized by the universality of methods for assessing the level of environmental friendliness of real estate, which seems to be a very important advantage in the context of the existence of different building codes and regulations in different countries.

DGNB certification system and its methods have been without equal when it comes to compliance with the EU's definition of sustainability. One example is the life cycle assessment for the building environment - ENV2.4 Biodiversity - Green surfaces on the building: Planting greenery on additional surfaces on the building increases the land's biotope area is evaluated by special bonus: +10 points for a biodiversity, index $>30$ [5].

According to DGNB, the ecological impacts of the actual building are combined into a common parameter for the assessment of the total primary energy requirement of the building PEtot as an annual average value over the reference period applied for the certification by formula (1):

$$
\text { PEtot }=\text { PEnren }+ \text { PEren }+ \text { Sec }
$$


whereby PEnren - annual average non-renewable primary energy demand of the building throughout the reference period in $\left[\mathrm{kWh} /\left(\mathrm{m} 2 \mathrm{NFA}^{*} \mathrm{a}\right)\right]$;

PEren - annual average renewable primary energy demand of the building throughout the reference period in [kWh /(m2 NFA*a)];

Sec - average annual energy demand from secondary fuels of the building throughout the reference period in [ $\mathrm{kWh} /(\mathrm{m} 2 \mathrm{NFA} * \mathrm{a})]$.

The use of green standards provides the following advantages: promotes the introduction of the best environmental and energy-efficient technologies, equipment and materials in the design, construction and operation processes; improves the system for managing the operation of the building and saving operational costs by extending the service life of the building, reducing the frequency of ongoing repairs; creates more comfortable working and living conditions, etc.

The effectiveness of green standards in the environmental certification of buildings has led to the development by many countries of their own national standards for green building: Australia (Green Star), Brazil (AQUA), Finland (PromisE), France (HQE), Hong Kong (HK BEAM), India (GRIHA), Italy (Protocollo Itaca / Green Building Counsil Italia), Spain (VERDE), Canada (LEED Canada / Green Globes), China (GBAS), Malaysia (GBI Malaysia), Netherlands (BREEAM Netherlands), New Zealand (Green Star NZ), Portugal (Lider A), Singapore (Green Mark), Taiwan (EEWH), Philippines (BERDE / PHILGBC), Switzerland (Minergie), South Africa (Green Star SA), Japan (CASBEE), Thailand (TREES) and etc. So, Thailand adopts the solution to legislate the act of energy conservation promotion from the foreign country in 1992 and give force the acts in April 3rd, 1992. This act of energy conservation promotion was aimed to support efficient production and materials for energy savings [6,7].

In world practice, the demand for housing, office buildings and industrial facilities that meet environmental requirements for real estate objects is increasing [8]. More than 500,000 buildings in the world have already been evaluated using BREEAM and LEED methods, and more than 2.5 million are under evaluation. Certification of the building is carried out by awarding points according to various criteria: reduction of energy and water consumption, compliance with high requirements for indoor and outdoor air quality, use of alternative energy sources, wastewater treatment, application of environmentally friendly building materials, etc. in under construction, designed and operated facilities [9].

In Russia, unlike European countries, the system of ecodevelopment is only being formed, therefore the implementation of green construction projects is of a single, experimental nature. The Russian rating system "Green Standards" - RGBS was developed on the basis of LEED, BREEAM, DGNB system standards, as well as the Canadian Green Building Initiative. For the orientation of the Russian construction industry on environmental requirements, the following were developed and put into effect:

Rules of functioning of the system of voluntary certification of real estate objects (2010) - "Green standards";

- Standard of the National Association of Builders "Green Building". The buildings are residential and public. The rating system for assessing the sustainability of habitat quality (2010);

- Rating system of integrated assessment of energy efficiency, environmental and sanitary and epidemiological safety of buildings; 
- "Fundamentals of state policy in the field of environmental development of the Russian Federation for the period until 2030" (2012);

- GOST R 54954-2012 "Conformity assessment. Environmental requirements for real estate "(2013)

However, there are not so many buildings in Russia that have received a green certificate, most of them are in Moscow and St. Petersburg, although some examples of the implementation of green construction exist in other regions (Nizhny Novgorod, Voronezh, Kimry, Tula region) [10]. In addition, it should be noted that in Russia the vast majority of objects that received a Green certificate refers to office or industrial and warehouse buildings ( 58 and $23 \%$, respectively), and not to residential buildings (2\%) [11]. Therefore, russian ecodevelopment today is not an absolute necessity dictated by external factors, but the desire of the developer to use the competitive advantages of a unique project, as tenants of office buildings are ready to invest in the creation of the image of a socially responsible company, offering a comfortable working environment for its employees. In residential construction, the relative high cost of environmentally friendly technologies makes them still inaccessible to the mass consumer - they are used primarily in the construction of luxury housing. This is largely due to the creation, availability and price policy of environmentally friendly materials and devices.

\section{Results and discussion}

In our view, to the legal documents in European countries, various incentives have been developed, including those enshrined in legal documents. These incentives encourage the use of sustainable technologies and reduce the impact on the environment. So, earlier the requirement to use renewable energy sources was a kind of legislative "whip", but the introduction of new incentive measures (incentive tariffs, incentives for the use of renewable heat sources, schemes for increasing capital tax deductions) became an economic "carrot", demonstrating the successful practical implementation of the "carrotand-stick" [12]. The introduction of incentive measures will ensure a steady growth of green construction in our country, create conditions for the greening of the construction industry, sustainable development of urban areas.

Ecodevelopment is not only the construction of high-tech buildings that reduce the burden on the environment, but also the health of their inhabitants. The principles of green construction correspond to the methodological basis for the construction of smart cities and smart buildings and suggest the use of environmental technologies and ecological design, the concept of innovation for sustainable development in construction [14-18]. One of the structural elements of smart buildings is the green roof. In smart cities on green roofs, you can arrange recreation areas, sports grounds or apply them for a different purpose. Using the green roof allows: to reduce the average air temperature in the area of their location; harmful electromagnetic radiation and noise; heat loss of the building; dustiness; filter air, reduce the load on climate systems; improve the microclimate of the upper floors of the building; improve the aesthetics of the building. For example, the green roof of the California Academy of Sciences in San Francisco, USA holds up to $98 \%$ of storm runoff.

\section{Conclusions}

This research is aimed for appropriate techniques and design and implementation of development schemes in the green buildings. Green standards are the basic rules for ecodevelopment, and eco-friendly real estate is the main trend in the construction market of 
foreign countries [12,13]. The elaboration of construction ecodevelopment is impossible without the development of an institutional eco-environment that allows not only to create high-tech solutions in green technologies, but also to introduce them at the design, construction and operation stages of real estate.

This work was financially supported by Ministry of Science and Higher Education of the Russian Federation (\#NSh-3492.2018.8).

\section{References}

1. Technical report by the United Nations Statistical Commission (UNSC) on the process of the development of an indicator framework for the goals and targets of the post-2015 development agenda (Working draft). (Sustainable Development Knowledge Platform, United Nations (19 March 2015).

2. E. Korol, N. Shushunova, Procedia Engineering, 161, (2016)

3. E. Korol, N. Shushunova, Procedia Engineering, 153 (2016)

4. A. A. Volkov, L. V. Sukneva, Procedia Engineering, 91 (2014)

5. On-line: http://www. https://www.dgnb.de

6. C. Luangcharoenrat, S. Intrachooto, Journal of architectural and planning research and studies, 10 (2013)

7. A. Lohmeng, K.Sudasna, T. Tondee, Energy Procedia, 138 (2017)

8. L.V. Plotnikova, Ecological management of urban environment quality in highly urbanized areas: abstract of the dissertation, Dr. Econ. Sciences, Moscow (2009)

9. P.G. Grabovyi, L.A. Manukhina, Real Estate: Economics, Management, 1-2 (2014)

10. K. E. Gabrin, O.N. Luchevnikova, Investment and innovation management, 4 (2017)

11. 11. V.M. Filippenko, R.G. Abakumov, Innovative science, 04-1 (2017)

12. N.Yu. Stelmakh, BF BSEU, (2010)

13. S.G. Sheina, E.N. Minenko, Construction-2013: materials of the international scientific and practical conference, Rostov n / a: Growth. state. builds. Univ., (2013)

14. O.A. Korol, Construction Materials, 6 (2015)

15. V.G. Borkovskaya, Advanced Materials Research, Vol. 945-949, Chapter 22 (2014)

16. V.G. Borkovskaya, Applied Mechanics and Materials, Vol. 467, Chapter 2, (2013)

17. V.G. Borkovskaya, Applied Mechanics and Materials, Vol. 475-476, Chapter 15, (2013)

18. V.G. Borkovskaya, D. Passmore, MATEC Web of Conference 2018, Vol. 193 (2018) 